\title{
Impairment of Ovarian and Uterine Cellular Architecture, Total Protein Content: A Consequence of Lead Nitrate Induced Increased Free Radical Load
}

\author{
Seema Rai", Muddasir Basheer, Deepika Acharya, Hindole Ghosh, Pritam Bhattacharya \\ Department of Zoology, School of Life Sciences, Guru Ghasidas Vishwavidyalaya (A Central University), Bilaspur, Chhattisgarh
}

Email address:

drseemakamlesh@gmail.com (S. Rai), muddasirbasheer@gmail.com (M. Basheer), acharyadeepika09@gmail.com (D. Acharya), hindole663@gmail.com (H. Ghosh) pritanncc@yahoo.in (P. Bhattachrya)

\section{To cite this article:}

Seema Rai, Muddasir Basheer, Deepika Acharya, Hindole Ghosh, Pritam Bhattacharya. Impairment of Ovarian and Uterine Cellular Architecture, Total Protein Content: A Consequence of Lead Nitrate Induced Increased Free Radical Load. Advances in Bioscience and Bioengineering. Vol. 3, No. 5, 2015, pp. 49-55. doi: 10.11648/j.abb.20150305.11

\begin{abstract}
A significant decrease in weight of ovary and oviduct of female rats was noted following lead nitrate administration with a dose $80 \mathrm{mg} / \mathrm{kg}$ body weight/day for 28 days. Histomicrogaphs of ovary showed marked inhibition of follicular growth as judged by gradual decrease oocyte size, absence of theca and granulosa layer, resulting absence of graafian follicle. Oviduct showed shrinkage in lumen and damage in perimetrium cells. Increase in total protein of ovary and oviduct after lead nitrate treatment denoting changes at translational level of concern gene to prevent the normal physiology. A significant increase in the thiobarbituric acid reactive substances (TBARS) of both tissues denotes increased free radical load resulted in the damage of cellular architecture. Findings, suggest that lead entering to the biological system via environment and other widely used industrial product may interfere with the normal reproductive physiology and folliculogenesis could be one of the cause of female infertility.
\end{abstract}

Keywords: Lead Nitrate Toxicity, TBARS, Ovary, Oviduct

\section{Introduction}

The toxicity caused by heavy metal toxicity is a serious worldwide problem which affects the growth, reproductive performance, life span and therefore health of all living organisms adversely [1]. Lead $(\mathrm{Pb})$ is regarded as a potent occupational toxin and its toxicological manifestations are well known. It is one of the earliest metals discovered by the human race and is ubiquitous. Unique properties of lead, like softness, high malleability, low melting point, ductility, and resistance to corrosion are responsible for its widespread usage in different industries like automobiles, paint, ceramics, plastics, etc. This in turn has led to a manifold rise in the occurrence of free lead in biological systems and the inert environment.

Lead is an environmental and industrial pollutant and heavy metal found in almost all phases of biological systems. The non biodegradable nature of lead is the prime reason for its prolonged persistence in the environment. Human exposure to lead occurs through various sources like leaded gasoline, industrial processes such as lead smelting. Lead exposure produce reversible changes in mood and personality as fatigue, irritability, depression etc [2]. It causes a number of undesirable changes including neurological [3-4], behavioural [5-6], immunological [7-8], renal [9-11], hepatic [12], cardiovascular system and hematological dysfunctions $[13,6]$. Children which are exposed to lead are reported to have adverse effects on central nervous system and kidneys [14]. Acute toxicity of lead occurs due to occupational exposure whereas chronic toxicity on the other hand is more common in occurrence. It can be much more severe if not treated in time and is characterized by persistent vomiting, encephalopathy, lethargy, delirium, convulsions and Coma [15-16].

Lead is known to cause a number of adverse effects on the reproductive system in both men and women. Increased levels of lead have been associated with reduced sperm count, poor semen motility, and abnormal sperm morphology, particularly of the sperm head [17-19]. Women on the other hand, are more susceptible to infertility, miscarriage, premature membrane rupture, pre-eclampsia, pregnancy hypertension and premature delivery [20]. During the gestation period, direct influence of lead on the developmental stages of the fetus has 
also been reported [21].

Data suggest that lead enters the human body primarily through ingestion and inhalation [22]. Maternal lead crosses the placenta to the foetus [23]. Previously, most research in the area of toxicology and environmental and occupational health involved male subjects. This in turn has led to a manifold rise in the occurrence of free lead in biological systems and the inert environment. Oxidative stress is the imbalance between the production of free radicals and the ability of body to detoxify the reactive species or repair the damage, oxidative stress has been reported to be the major mechanism of lead toxicity [24]. The other mechanism is the ionic mechanism. This arises due to its ability to substitute other bivalent cations like $\mathrm{Ca}^{2+}, \mathrm{Mg}^{2+}, \mathrm{Fe}^{2+}$ and monovalent cations like $\mathrm{Na}^{+}$, affecting various fundamental biological processes of the body [25].There is dearth of literature about the direct actions of heavy metals on the female reproductive system, fertility and development.

We therefore aimed to note the effect of lead nitrate exposure on ovary and oviduct tissue of rat through the assessment of alterations in gravimetric, histological and biochemical changes.

\section{Material and Methods}

The experiment was conducted during the months of February and March. The rats were of Wistar strain having a weight of $130 \pm 10 \mathrm{~g}$ and were purchased from the local supplier and were maintained at animal house of the SLT Institute of Pharmalogical Science, Guru Ghasidas University in polypropylene cages. The cages were maintained in well-ventilated room exposed to ambient condition and were fed with the standard rat feed and water ad libitum. Experimental protocol was approved by Institutional Ethical Committee, Department of Zoology, Guru Ghasidas Vishwavidyalaya, Bilaspur (Registration number: 1321/PO/ReBi/S/10/CPCSEA). After acclimatization the animals were randomly divided into two groups each consisting of six animals (Table 1).

Table 1. Experimental Groups.

\begin{tabular}{lll}
\hline Group & Treatment & Number of Animals \\
\hline Control & Normal saline & 6 \\
Lead Nitrate & (80mg $/ \mathrm{kg}$ body. wt) & 6 \\
\hline
\end{tabular}

At the end of the experiment ( 28 days), the animals were anaesthetized and sacrificed. The reproductive tissues were subjected to study following parameters.

\subsection{Gravimetric Analysis}

Ovary and oviduct of control and lead nitrate treated groups were taken after completion of the experiment and weighed. The differences were expressed in gram $(\mathrm{g})$ and documented.

\subsection{Histological Observation}

Ovaries of the controls and lead nitrate treated rats were cleaned from adherent fat and connective tissue, and fixed in
Bouin's fixative for at least 24 hours.. Then the Ovary and Oviducts were was processed and embedded. Tissues were cut into 6 microns thick sections using rotary microtome (Leica RM 2125-RT 5). The sections were stained with Haematoxylin and Eosin (H\&E) for routine histological study. The photomicrographs of respective groups were captured by Trinocular Research Microscope (Leica DM 2000) and documented (Magnification 40X, 100X).

\subsection{Lipid Peroxidation Assay (LPO)}

Free radicals have a very short half-life, which makes them very hard to measure in the laboratory. A commonly used alternate approach measures markers of free radicals rather than the actual radical. Thiobarbituric acid reactive substances (TBARS) are produced during oxidative damage to cell membrane. Malonaldehyde (MDA), one of the major lipid breakdown product and commonly used parameter to assess lipid peroxidation. Ovaries and Oviducts were excised and weighed for the preparation of $10 \%$ tissue homogenates in 20 $\mathrm{mM}$ Tris Hydrochloride (HCl) buffer $(\mathrm{pH}$ 7.4). The homogenates were centrifuged at $3000 \mathrm{~g}$ for $15 \mathrm{~min}$ at $4^{\circ} \mathrm{C}$ and supernatant was subjected to Thiobarbituric acid (TBA) assay by mixing it with $8.1 \%$ SDS, $20 \%$ acetic acid, $0.8 \%$ TBA and boiling for $1 \mathrm{~h}$ at $95^{\circ} \mathrm{C}$. The reaction mixture was immediately cooled in running water and vigorously shaken with n-butanol and pyridine reagent $(15: 1)$ and centrifuged for $10 \mathrm{~min}$ at 1500 g. The absorbance of the upper phase was measured at $534 \mathrm{~nm}$ LPO was expressed as TBARS in $\mathrm{nmol} / \mathrm{g}$ tissue wt., by taking $1,1,3,3$ tetraethoxy propane (TEP) as standard. The standard curve was calibrated using $10 \mathrm{nM}$ concentration of TEP [26-27].

\subsection{Protein Concentration}

Total protein content was estimated following the method of [28]. The concentrations of the sample proteins were calculated from the standard curve of bovine serum albumin (BSA). A standard solution having a concentration of $1 \mathrm{mg} / \mathrm{ml}$ was prepared. Reagent (I \& II) were prepared. $0.2 \mathrm{ml}$ of BSA working standard was taken in 5 test tubes and distilled water was addaed to make it $1 \mathrm{ml}$. The test tube with $1 \mathrm{ml}$ distilled water served as blank. $4.5 \mathrm{ml}$ of Reagent I was added and incubated for 10 minutes. After incubation $0.5 \mathrm{ml}$ of reagent II was added to it and incubate for 30 minutes again. Absorbance was measured at $660 \mathrm{~nm}$ and the standard graph was plotted. The amount of protein present in the given sample was estimated from the standard graph.

Statistical Analysis

Statistical analysis was done for obtained data following Student's' test. The values were considered significant when $P$ $<0.05$ and 0.001 .

\section{Results}

\subsection{Change in Tissue Weight}

A significant decrease $(\mathrm{P}<0.001)$ was noted in weight of ovary and oviduct following exposure of lead nitrate for 28 
days in female rats when compared to control tissues (Fig. 1)

\subsection{Alteration in Cellular Architecture Ovary and Uterine Duct}

Treatments of $\mathrm{PbNO} 3$ at the dose of $(80 \mathrm{mg} / \mathrm{kg}$ body weight $)$ for 28 days resulted in inhibition of follicular development and finally lead to the absence of Graafian follicle

(Fig.2). Uterine duct showed significant shrinkage in the lumen along with necrosis in outer layer i.e, perimetrium (Fig.3) when compared to the control tissue of ovary and oviduct.

\subsection{Biochemical Parameters}

\subsubsection{Alteration in Lipid Peroxidation}

A significant increase $(\mathrm{P}<0.001)$ was found in the TBARS level in ovary and oviduct following the treatment of lead nitrate when compared to the control tissues (Fig. 4 and Fig. 5). Lead nitrate treatment resulted in significant increase in serum TBARS level when compared with control serum (Fig. 6)

\subsubsection{Alterations in Total Protein Content of Ovary and Oviduct}

A significant $(\mathrm{P}<0.001)$ increase was found in the level of proteins in ovary and oviduct following the daily oral

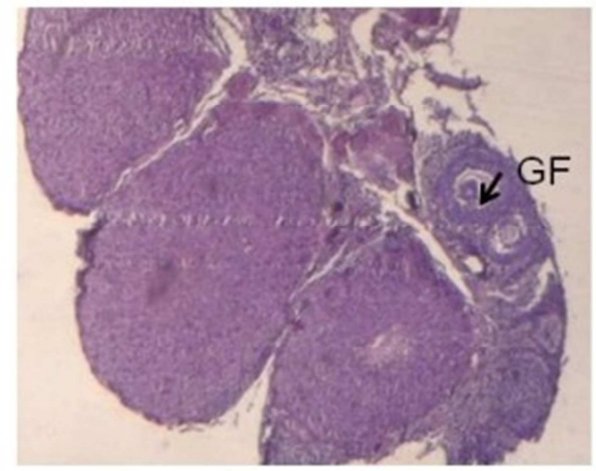

a.

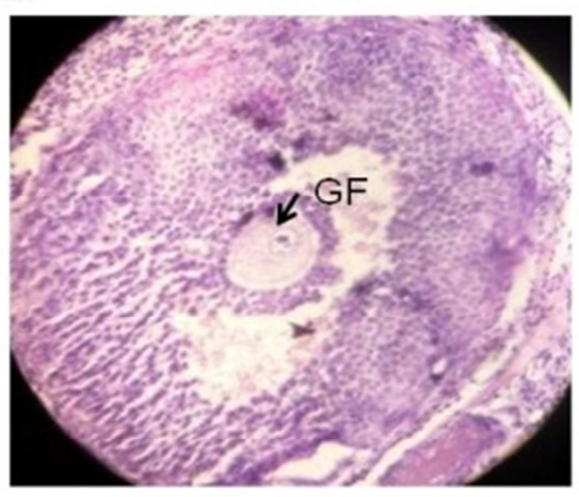

c. administration of lead as compared to control (Fig. 7 and Fig. 8) The elevation in protein content is mainly attributed to environmental assaults including toxins, pollutants, and poisons and is mainly due to the production of proteins which rescue the cells from harm [29]. This elevation in proteins may also be due to the destruction of tissue during which the proteins are released.

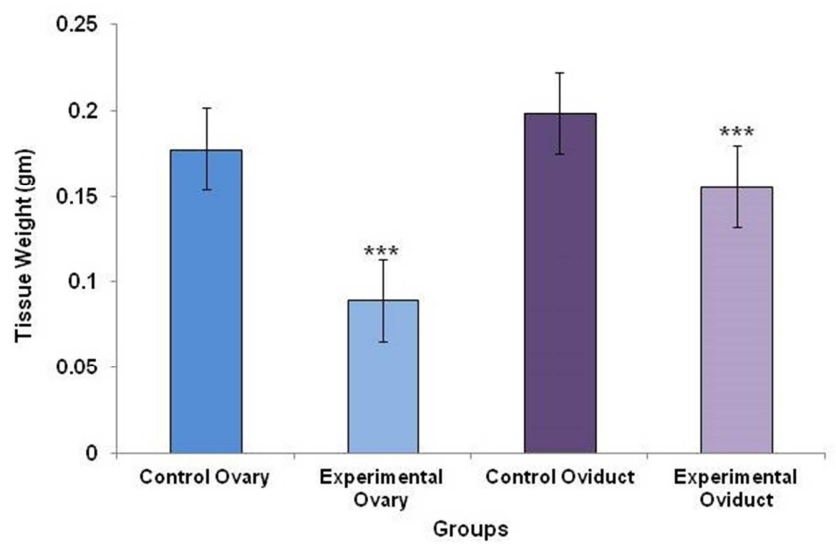

Fig. 1. Effect of $\mathrm{PbNO}_{3}(80 \mathrm{mg} / \mathrm{kg}$ body weight/day) on the weight of ovary and oviduct of female rats. The results are expressed as Mean $\pm S E M, N=6$, Control $=$ Normal saline $(0.9 \%)$,Experimental=lead nitrate treated, $* * * P<0.001$.

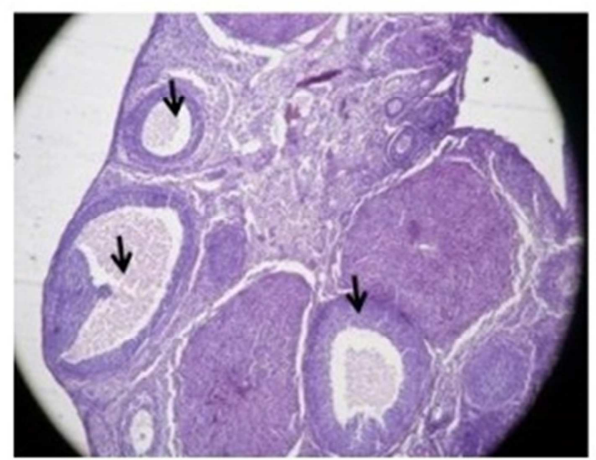

b.

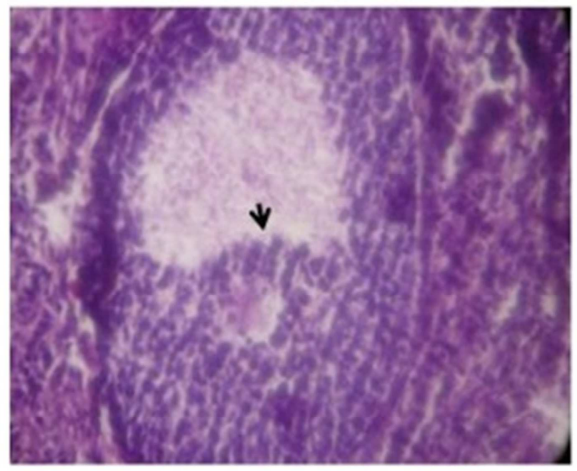

d.

Fig. 2. Histomicrograph of ovary treated with lead nitrate and stained with H \& E (a) Control [40X] and (b) Control [100X] showing normal cellular architecture with oocyte and Graafian follicle (GF), (c) lead treated [40X] and (d) lead treated [100X] showing degenerative changes in granulosa cell and degenerative oocyte. 


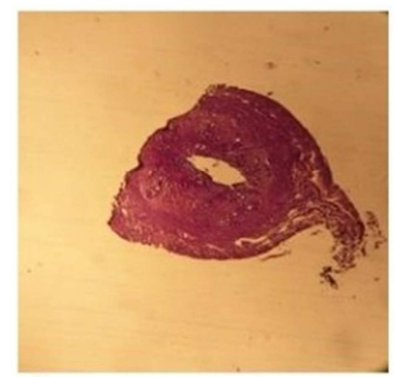

a.

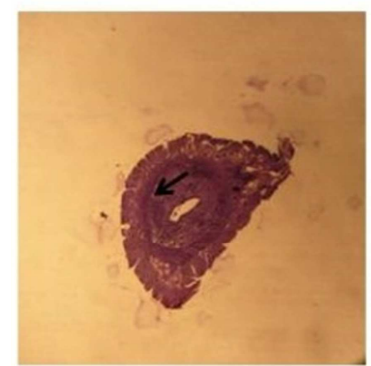

c.

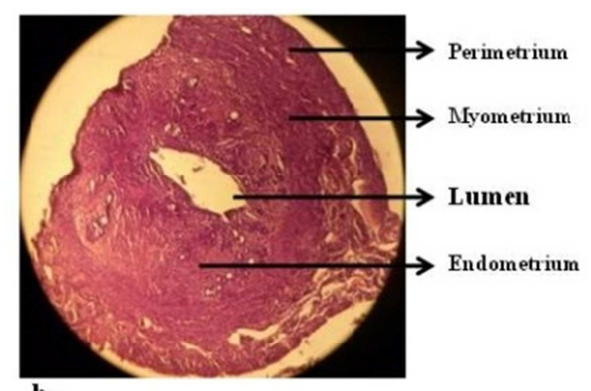

b.

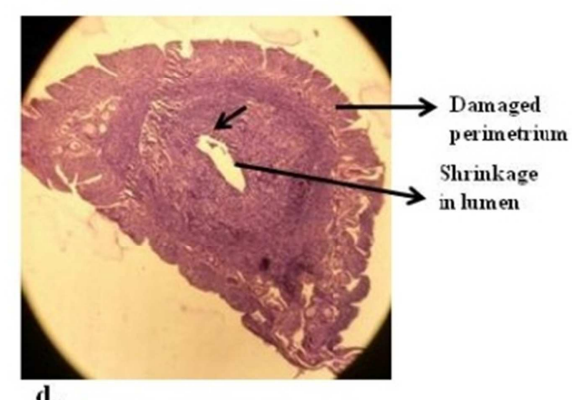

Fig. 3. Histomicrograph of oviduct treated with lead nitrate and stained with H\& E (a) Control [40X] and (b) Control [100X] showing normal lumen opening with normal cellular architecture of perimetrium, myometrium and endometrium, (c) lead treated [40X] and (d) lead treated [100X] showing shrinkage in lumen and degeneration in perimetrium.

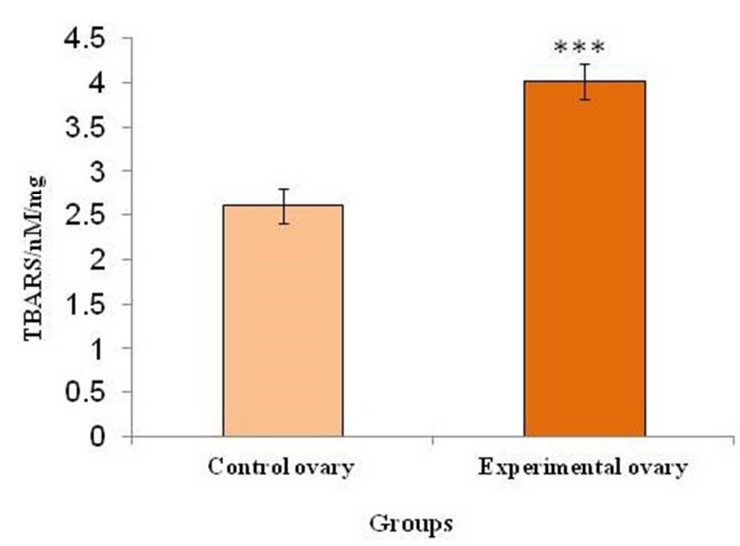

Fig. 4. Effect of $\mathrm{PbNO}_{3}(80 \mathrm{mg} / \mathrm{kg}$ body weight/day) on the TBARS level of ovary in female rats. The results are expressed as Mean $\pm S E M, N=6$, Control $=$ Normal saline $(0.9 \%)$, Experimental=lead nitrate treated, $* * * P<0.001$.

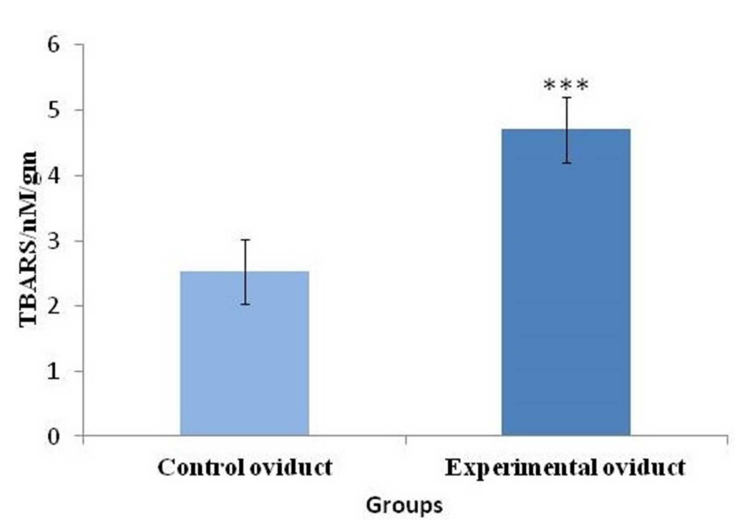

Fig. 5. Effect of $\mathrm{PbNO}_{3}(80 \mathrm{mg} / \mathrm{kg}$ body weight/day) on the TBARS level of oviduct in female rats. The results are expressed as Mean $\pm S E M, N=6$, Control $=$ Normal saline $(0.9 \%)$, Experimental=lead nitrate treated, $* * * P<0.001$

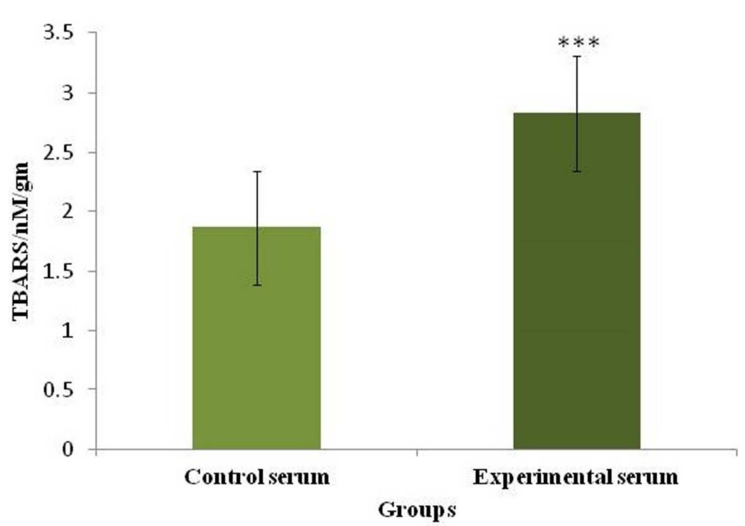

Fig. 6. Effect of PbNO3 ( $80 \mathrm{mg} / \mathrm{kg}$ body weight/day) on the TBARS level of serum in female rats. The results are expressed as Mean $\pm S E M, N=6$, Control $=$ Normal saline $(0.9 \%)$, Experimental=lead nitrate treated, $* * * P<0.001$.

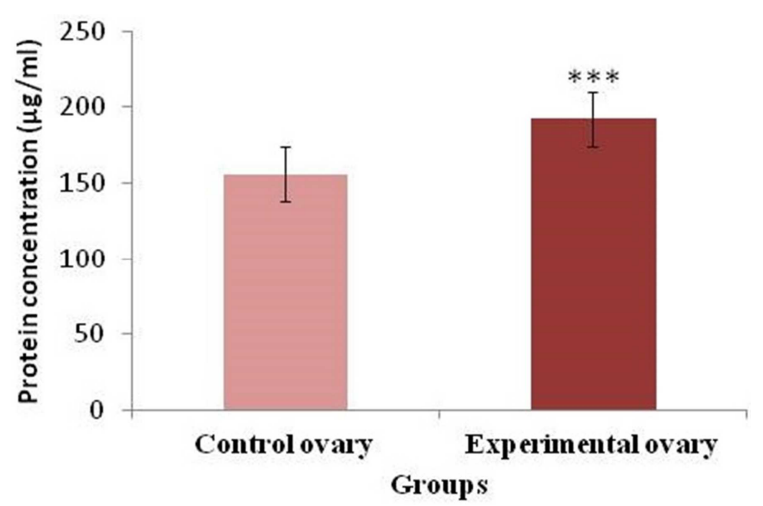

Fig. 7. Effect of PbNO3 (80 mg/kg body weight/day) on the protein concentration of ovary in female rats. The results are expressed as Mean \pm SEM, $N=6$, Control= Normal saline $(0.9 \%)$, Experimental=lead nitrate treated, $* * * P<0.001$. 


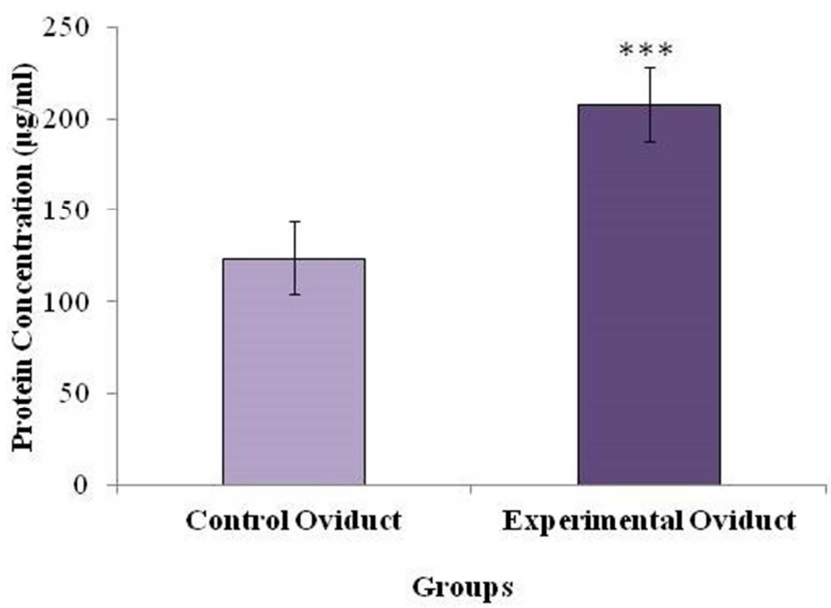

Fig. 8. Effect of PbNO3 (80 mg/kg body weight/day) on the protein concentration of oviduct in female rats. The results are expressed as Mean \pm SEM, N=6, Control $=$ Normal saline (0.9\%), Experimental=lead nitrate treated, $* * * P<0.001$

\section{Discussion}

In the present study exposure of The lead nitrate exhibited most prominently and dominantly towards the histological alterations in the various cellular components of ovary and oviduct. The microscopic examination of histological sections of the ovary revealed damages and reduction in the number of primordial follicle. Finally resulted in the disappearance of the theca and granulosa layer. Histopathological examination of the ovarian tissues showed diffused atretic and degenerative changes of growing and mature follicles. Lead exposure caused atresia in all stages of follicle formation which is in support of the previous finding by [30]. These investigations clearly emphasize that lead exposure is extremely dangerous for ovarian and oviduct tissue which may lead to reproductive disorders, Several lead containing compounds can cause enzyme dysfunction, which probably accounts for their mechanisms of toxicity on the reproductive system, which might have resulted in terms of shrinkage of lumen and apoptic damages might have resulted due to increase in free radical load. This elevation in TBARS level is due to the production of reactive species which are the main reason for oxidative stress. This free radical is a major cause of tissue damage which might have resulted due to exposure of lead nitrate.

Lead decrease the level of antioxidants and increase the concentration of free radicals and lipid peroxidation [31]. Oxidative stress initiates the lipid peroxidation which results in DNA damage. DNA damage is eminent because lead exposure causes oxidative stress and lipid peroxidation. This finding certainly reflects the lead nitrate as a most toxicant for which ovary and oviducts are very sensitive and a chronic exposure may result for female infertility. Reactive oxygen species affect a variety of physiological functions such as oocyte maturation, ovarian steroidogenesis, ovulation [32]. In addition to the above mentioned changes the treated rat group also showed irregularity in the estrous cycle [33-34].

The elevated protein level in both of the tissues may be the effect of the change of the physiology. May be there are some genes which are responding to prevent the abnormal change and damage of the tissue. But the correct reason is not detectable in the present study, it can be understood that which protein is responding in this case in more advance study i.e. at translational level. Levels of lead in soft tissues appear to be relatively constant during life, despite a fairly high turnover rate [35]. Further autopsy studies suggest that testis is one of the repositories of soft tissue lead. Such kind of reposition of soft tissue lead can be explained on the basis of the fact that soft tissue contains numerous proteins to which lead may bind. in this regard metallothionin protein is reported in the hepatocytes to which lead may bind because of its high affinity [36]. Research finding so far reported summarises that most of the heavy metals released in the high amount to the wastewater bodies creates serious health leading to reduced growth and development, cancer, organ damage, nervous system damage, and in extreme cases, death in animals including human beings [37]. Many other finding also supports the impairment and alteration in Cholesterol, HDL, LDL and Triglyceride content in aquatic animals like fishes of high food value exposed to arsenic and other heavy metals [38].

The higher concentrations of lead in tissues following occupational or experimental exposure were associated with oxidative damage of DNA, protein and lipid which suggests that lead induced oxidative stress play a role in lead induced toxic effects [12]. Since the lead exposure increases oxidative stress and lipid peroxidation, therefore it is suggested the alteration in oxidative stress induced following lead treatment could be the basis of resulted toxicity and impairment of reproductive tissue.

\section{Conclusions}

In conclusion lead alters the normal histology and the physiology of the ovary and oviduct. It also interferes with the development of different stages of follicles in the ovary. Our finding clearly demonstrates that lead has genotoxic and cytotoxic effect resulting in increased TBARS level. The elevation in protein content is can be correlated because of the increased environmental assaults including toxins, pollutants, and poisons which led to the production of proteins in order to rescue the cells from damages. Increased free radical load might have induced DNA damage and may be apoptosis in the ovary and oviduct of female rats resulted in the reproductive impairment which may further lead to the infertility in females. It is therefore suggested that lead exposure even at low level can affect female fertility in animals including humans.

\section{Acknowledgement}

Authors are highly thankful to the Department of Zoology, School of Life Sciences, Guru Ghasidas Vishwavidyalaya, Bilaspur Chhattisgarh for providing the facilities during the course of study and the financial assistance by UGC-BSR Start-up grant, New Delhi. 


\section{References}

[1] H. M. Perry, E. F. Perry, M. W. Erlanger, D. D. Hemphill, Trace Substances in Environmental Health. 3 (1974) 51.

[2] E. C. Foulkes, Biological effects of heavy metals, Vol. II, Metal Carcinogenesis U. R. C. Press, Boston, 1990.

[3] K. Soltanianejad, A. Kebriaeezadeh, B. Minaiee, Biochemical and ultrastructural evidences for toxicity of lead through free radicals in rat brain, Hum. Exp. Toxicol. 22 (2003) 417-433.

[4] D. C. Bellinger, Very low lead exposures and children's neurodevelopment current opinion in Pediat. 20 (2008) 172-177.

[5] M. De Marco, R. Halpern, H. M. T. Barros, Early behavioral effects of lead perinatal exposure in rat pups, Toxicol. 211 (2005) 49- 58.

[6] T. T. Adeniyi, G. O. Ajayi, O. A. Akinloye, Effect of Ascorbic acid and Allium sativum on tissue lead in female Rattus navigicus, Niger. J. Health Biomed. Sci. 7 (2008) 38-41.

[7] T. L. Bunn, G. S. Ladics, M. P. Holsapple, Developmental immunotoxicology assessment in the rat. Age, gender and strain comparisons after exposure to $\mathrm{Pb}$. Toxicol. Met. 11 (2001) 41-58.

[8] C. E. Rosenberg, N. E. Fink, A. Salibian, Humoral immune alterations caused by lead. Studies on an adults lead model, Acta. Toxicol. Argent. 15 (2007) 16-23.

[9] I. Vargas, C. Castillo, F. Posadas, Acute lead exposure induces renal heme oxygenase- 1 and decreases urinary $\mathrm{Na}+$ excretion, Hum. Exp. Toxicol. 22 (2003) 237-244.

[10] S. K. Rastogi, Renal effects of environmental and occupational lead exposure, Ind. J. Occup. Environ. Med. 12 (2008) 103-106.

[11] V. Sharma, S. Sharma, Pracheta, R. Paliwal, S. H. Sharma, Therapeutic efficacy of Withania somnifera root extract in the regulation of lead nitrate induced nephrotoxicity in Swiss albino mice, J. Pharm. Res. 4 (2011) 755-758.

[12] R. C. Patra, D. Swarup Effect of lead on erythrocyte antioxidant defence, lipid peroxide level and thiol groups in calves, Res. Vet. Sci. 68 (2000) 71-74.

[13] H. M. Mousa, A. A. Al- Qarawi, B. H. Ali, H. A. Abdula Rahman, S. A. Elmougy, Effect of lead exposure on the erythrocytic antioxidant levels in goat, J. Vet. Med.49 (2002) 531-534.

[14] J. K. Sangha, N. Kaur, J. Singh, Extent of heavy metal toxicity in the diet of school boys of Ludhiana, J. Res. Punjab. Agric. Univ. 38 (2001) 124-9.

[15] S. J. S. Flora, G. Flora, G. Saxena. Environmental occurrence, health effects and management of lead poisoning, (In: Jose, S. C, Jose, S., eds. Lead. Amsterdam: Elsevier Science B.V.). (2006). 158-228.

[16] J. M. Pearce, Burton's line in lead poisoning, Eur. neurol. 57 (2007) 118-9.

[17] B. H. Alexander, H. Checkoway, E. M. Faustman, C. van Netten, C. H. Muller, T. G. Ewers, Contrasting associations of blood and semen lead concentrations with semen quality among lead smelter workers. Am. J. Ind. Med. 34 (1998) 464-9.
[18] L. Eibensteiner, A. Del Carpio Sanz, H. Frumkin, C. Gonzales, G. F. Gonzales, Lead exposure and semen quality among traffic police in Arequipa, Peru, Int. J. Occup. Environ. Health. 11 (2005) 161-6.

[19] D. Lerda, Study of sperm characteristics in persons occupationally exposed to lead, Am. J. Ind. Med. 22 (1992) 567-71.

[20] S. J. S. Flora, V. Pachauri, G. Saxena. Arsenic, cadmium and lead. Reproductive and Developmental Toxicology. (Academic Press), (2011) 415-438.

[21] H. A. Saleh, G. A. El-Aziz, M. M. El-Fark, M. El-Gohary, Effect of maternal lead exposure on craniofacial ossification in rat fetuses and the role of antioxidant therapy, Anat. Histol. Embryol. 38 (2009) 392-399.

[22] Agency for Toxic Substances and Disease Registry (ATSDR), Toxicological Profile for Lead. (2007). US Department of Health and Human Services: Atlanta, US.

[23] B. L. Gulson, K. J. Mizon,M. J. Korsh, J. M. Palmer, J. B. Donnelly, Mobilization of lead from human bone tissue during pregnancy and lactation: A summary of long-term research, Sci. Total Environ. 303 (2003) 79-104.

[24] J. Xu, L. Ling-jun, W. U. Chen, W. Xiao-feng, F. U. Wen-yu, $\mathrm{X}$. Lihong, Lead induces oxidative stress, DNA damage and alteration of p53, Bax and Bcl-2 expressions in mice, Food. Chem. Toxicol. 46 (2008) 1488-1494.

[25] T. I. Lidsky, J. S. Schneider, Lead neurotoxicity in children: basic mechanisms and clinical correlates, Brain. 126 (2003) 5-19.

[26] R. L. Heath, and L. Packer, Photoperoxidation in isolated chloroplasts. I. Kinetics and stoichiometry of fatty acid peroxidation, Arch. of Biochem. and Biophy.. 125 (1968) 189.198.

[27] S. Rai, C. Haldar, R. Singh, Modulation of immunity in young-adult and aged squirrel, Funambulus pennanti by melatonin and p-chlorophenylalanine, Immunity \& Ageing. 6 (2009) 5. DOI: 10.1186/1742-4933-6-5.

[28] O. H. Lowry, N. J. Rosebrough, A. L. Farr, R. Randall, Protein measurements with the Folin phenol reagent, J. Biol. Chem. 193 (1951)265-80.

[29] W. J. Welch, How cell respond to stress, Scientific Amer. 268 (1993) 34-41.

[30] V. Dhir, P. Dhand, Toxicological Approach in Chronic Exposure to Lead on Reproductive Functions in Female Rats (Rattus Norvegicus), Toxicol. Inter. 17 (2010) 1-7.

[31] D. Y. Yu, W. F. Li, B. Deng, X. F. Mao, Effects of lead on hepatic antioxidant status and transcription of superoxide dismutase gene in pigs, Biol. Trac. Elem. Res. 126 (2008) 121-128.

[32] T. Suzuki, N. Sugino, T. Fukaya, S. Sugiyama, T. Uda, R. Takaya, A. Yajima and H. Sasano, Superoxide dismutase in normal cycling human ovaries: immunohistochemical localization and characterization, Fertil. Steril. 72 (1999) 720-726.

[33] M. J. Ronis, T. M. Badger, S. J Shema, P. K. Roberson, F. Shaik, Effects on pubertal growth and reproduction and reproduction in rats exposed to lead perinatally or continuously throughout development, J. Toxicol. Environ. Health. 13 (1998) 327-41. 
[34] R. Der, Z. Fahim, D. Hilderbrand, M. Fahim, Combined effect of lead and less protein on growth, sexual development and metabolism in female rats, Res Commun. Chem. Pathol. Pharmacol. 9 (1985) 723-38.

[35] P. S. Barry, A comparison of concentrations of lead in human tissues, Br. J. Ind. Med. 32 (1975) 119-139.

[36] D. H. Hamer, Metallothionein, Annu. Rev. Biochem. 55(1986) 913-951.
[37] O. B. Akpor, G. O. Ohiobor, T. D. Olaolu, Heavy metal pollutants in wastewater effluents: Sources, effects and remediation, Advances in Bioscience and Bioengineering.2 (2014) 37-43.

[38] J. Balasubramanian, A. Kumar, Study of effect of sodium arsenite on lipid metabolism of Heteropneustes fossilis and the chelating effect of zeolite, Advances in Bioscience and Bioengineering.1 (2013) 22-27. 